\title{
FAKTOR-FAKTOR YANG MEMPENGARUHI PRODUKTIVITAS TENAGA KERJA PADA BANGUNAN HIGH RISE DI REPUBLIK INDONESIA
}

\author{
Theodorus Alvin' ${ }^{1}$ dan Mega Waty ${ }^{2}$ \\ ${ }^{1}$ Program Studi Sarjana Teknik Sipil, Universitas Tarumanagara, Jl. Letjen S. Parman No.1 Jakarta \\ alvin.325160096@stu.untar.ac.id \\ ${ }^{2}$ Program Studi Sarjana Teknik Sipil, Universitas Tarumanagara, Jl. Letjen S. Parman No.1 Jakarta \\ mega@ft.untar.ac.id
}

Masuk: 18-07-2020, revisi: 09-08-2020, diterima untuk diterbitkan: 02-11-2020

\begin{abstract}
Developments in construction industry are growing rapidly, making it more competitive among contractors. Factors like cost, financial status, enviromental and quality control, safety management, project team and trained labor become a consideration for choosing a contractor to do certain project. The labor itself consuming almost 30 until 50 percent of total project's cost. Labor its very closely related to productivity where the lower productivity rate, the more chance delay will occur. The purpose of this research is to identify factors that affecting labor productivity at high rise building construction. The Methodology of this research is survey where the corespondents are who currently working or had been working as staff at high rise construction. After that, the result of the survey being tested for validity and reliability. After the validity and reliability test, these factors are being ranked to see what is the strongest factor that affecting labor productivity. There are 23 factors that affecting labor productivity and these factors comes from 4 main group factor which is Management, Technical factor, the labor, and external factor. From these 4 group, management group factor is the most affecting labor productivity and supervision of the worker is the most affecting labor productivity.
\end{abstract}

Keyword: labor productivity; management group factor; High Rise Building

\begin{abstract}
ABSTRAK
Dewasa ini, perkembangan pada dunia konstruksi kian pesat serta persaingan antar kontraktor semakin ketat. Faktorfaktor seperti biaya, status keuangan, pengendalian lingkungan, manajemen mutu, manajemen keamanan, project team, dan para tenaga kerja yang terlatih menjadi pertimbangan penting saat pemberian tugas ke kontraktor. Tenaga kerja sendiri menyumbang biaya sebesar 30\% sampai dengan $50 \%$ dari nilai total proyek dan tenaga kerja erat kaitannya dengan produktivitas dimana semakin rendah produktivitas tenaga kerja maka semakin besar peluang terjadi keterlambatan pada pekerjaan. Tujuan dari penelitian ini yaitu mengidentifikasi faktor-faktor apa saja yang mempengaruhi produktivitas tenaga kerja pada bangunan High Rise di Republik Indonesia. Metode penelitian ini menggunakan metode survey dimana kuesioner ditujukan kepada staff yang pernah bekerja di proyek bangunan High Rise di Republik Indonesia. Setelah itu hasil survey akan diuji validitas dan uji reliabilitas lalu terakhir dilakukan pemberian peringkat pada faktor-faktor yang mempengaruhi produktivitas tenaga kerja. Terdapat 23 faktor yang mempengaruhi produktivitas tenaga kerja dimana faktor-faktor ini merupakan bagian dari 4 Grup faktor yaitu faktor manajemen, faktor teknis, faktor tenaga kerja, dan faktor eksternal. Dari ke-empat grup faktor ini, yang paling mempengaruhi yaitu Grup Faktor Manajemen dan dari 23 faktor yang paling mempengaruhi yaitu pengawasan/supervisi terhadap tenaga kerja.
\end{abstract}

Kata kunci: tenaga kerja; produktivitas; faktor manajemen; High Rise Building

\section{PENDAHULUAN}

Dewasa ini, perkembangan pada dunia konstruksi kian pesat serta persaingan antar kontraktor semakin ketat. Kontraktor yang dapat mengerjakan proyek dengan kualitas dan harga yang baik semakin diminati oleh client dan masyarakat.

Faktor-faktor seperti biaya, status keuangan, pengendalian lingkungan, manajemen mutu, manajemen keamanan, project team, dan para tenaga kerja yang terlatih menjadi pertimbangan penting saat pemberian tugas ke kontraktor.

Dalam konteks ini, produktivitas tenaga kerja memainkan peran penting dalam keberhasilan finansial (Liu and Ballard 2008) dalam Rivas et al (2015). Secara teori, produktivitas didefinisikan sebagai output dibagi dengan input. 
Dalam dunia konstruksi, produktivitas lebih sering didefinisikan sebagai output unit produksi per orang-jam (Neil and Knack 1984; Thomas 2000) dalam Rivas et al (2015).

Semakin rendah produktivitas pekerja maka semakin besar peluang terjadi keterlambatan pada pekerjaan. Sebaliknya, jika produktivitas pekerja semakin tinggi maka peluang terjadinya keterlambatan semakin kecil. Beberapa penulis melaporkan bahwa tenaga kerja menyumbang biaya sebesar $30 \%$ sampai $50 \%$ dari nilai total proyek (Harmon and Cole 2006; Hanna 2001) dalam Rivas et al(2015), sehingga implementasi manajemen yang baik untuk meningkatkan produktivitas para pekerja bukan suatu pilihan melainkan suatu keharusan. Dengan memperhatikan hal yang telah disampaikan pada penjabaran latar belakang, maka akan menghasilkan rumusan permasalahan sebagai berikut:

1. Apa grup faktor yang mempengaruhi produktivitas tenaga kerja pada bangunan High Rise?

2. Apa saja faktor dari masing-masing grup faktor yang paling mempengaruhi produktivitas tenaga kerja pada bangunan High Rise?

3. Apa faktor yang paling mempengaruhi produktivitas tenaga kerja secara keseluruhan pada bangunan High Rise?

4. Apa saja faktor yang paling mempengaruhi produktivitas tenaga kerja menurut para Enginee ?

5. Apa saja faktor yang paling mempengaruhi produktivitas tenaga kerja menurut Profesional Engineer?

Berdasarkan masalah yang dirumuskan pada rumusan masalah, maka tujuan dari penulisan topik ini adalah:

1. Untuk mengetahui grup faktor apa yang paling mempengaruhi produktivitas tenaga kerja pada bangunan High Rise.

2. Untuk mengetahui faktor dari masing-masing grup faktor yang mempengaruhi produktivitas tenaga kerja pada bangunan High Rise.

3. Untuk mengetahui faktor yang paling mempengaruhi produktivitas tenaga kerja secara keseluruhan pada bangunan High Rise.

4. Untuk mengetahui faktor apa saja yang paling mempengaruhi produktivitas tenaga kerja menurut para Engineer.

5. Untuk mengetahui faktor apa saja yang paling mempengaruhi produktivitas tenaga kerja menurut Professional Engineer.

\section{Proyek konstruksi}

Menurut Wulfram (2005) Proyek konstruksi adalah sebuah rangkaian kegiatan yang hanya satu kali pelaksanaannya, dan umumnya memiliki jangka waktu yang pendek. Dimana kegiatan tersebut, terdapat suatu proses mengolah sumber daya proyek menjadi suatu hasil kegiatan yang dalam konteks ini, hasil kegiatan tersebut adalah bangunan. Menurut Rani (2016) Secara umum, konstruksi ada 2 macam yaitu:

1. Konstruksi bangunan gedung, terdiri atas: bangunan gedung, perumahan, hotel, dan lain-lain

2. Konstruksi bangunan sipil, seperti jembatan, jalan, lapangan terbang, terowongan, irigasi, bendungan, dan lain lain,

Selain itu, dikenal juga 4 tipe konstruksi lain yaitu :

1. Konstruksi pemukiman (Residental Construction)

Konstruksi ini meliputi konstruksi hunian, komplek permukiman. Perencanaan dimana yang diperlukan antara lain seperti menata ruang dan memperkirakan perkembangan hingga 20 tahun mendatang, penataan sistem drainase sehingga terhindar dari permasalahan seperti genangan air.

2. Konstruksi gedung (Building Construction)

Konstruksi ini meliputi gedung kantor, gedung kuliah, gedung bank dan lain-lain. Dimana perencanaan yang diperlukan untuk konstruksi jenis ini yaitu penyediaan hidrant untuk mengatasi kebakaran serta fasilitas lift untuk bangunan seperti gedung kuliah yang lebih dari 2 lantai dimana hal ini ditujukan untuk dosen yang berusia tua. Salah satu contoh manajemen konstruksi yang buruk dari konstruksi gedung yaitu timbulnya suara ribut dari atap pada saat angin kencang pada gedung kuliah.

3. Konstruksi Rekayasa Berat (Heavy Engineering Construction)

Sangat identik dengan penggunaan banyak alat berat. Diperlukan manajemen konstruksi yang baik agar penataan alat-alat berat tidak terbengkalai di lokasi karena tidak digunakan. Belum lagi biaya sewa peralatan alat berat yang mahal sehingga diperlukan manajemen konstruksi yang baik.

4. Konstruksi Industri (Industrial Construction)

Konstruksi ini meliputi pabrik dan lain-lain. Manajemen untuk proyek ini ialah memperhatikan dampak yang dihasilkan terhadap lingkungan sekitar seperti limbah hasil buangan serta polusi dan hal lain yang mengancam lingkungan sekitar. 


\section{Klasifikasi bangunan gedung}

Menurut Peraturan Pemerintah Republik Indonesia nomor 36 tahun 2005 tentang peraturan pelaksanaan UndangUndang nomor 28 Tahun 2002 Pasal 5 mengatakan bahwa klasifikasi bangunan gedung merupakan pengklasifikasian lebih lanjut dari fungsi bangunan gedung, agar dalam pembangunan dan pemanfaatan bangunan gedung dapat lebih tajam dalam penetapan persyaratan administratif dan teknisnya yang harus diterapkan. Menurut Pasal 5 ayat 7 mengenai ketinggian bangunan penetapan ketinggian bangunan dibedakan dalam tingkatan ketinggian: bangunan rendah(jumlah lantai bangunan gedung sampai dengan 4 lantai), bangunan sedang (jumlah lantaibangunan gedung 5 lantai sampai dengan 8 lantai), dan bangunan tinggi (jumlah lantai bangunan lebih dari 8 lantai).

\section{Tenaga kerja}

Menurut Soeharto (1999) Tenaga kerja merupakan salah satu sumber daya yang penting, seringkali penyediaannya terbatas, baik karena faktor kualitas ataupun hal-hal lain. Merekrut, menyeleksi, dan melatih tenaga kerja memerlukan biaya mahal dan membutuhkan waktu lama sebelum mereka siap pakai. Setelah mereka bergabung dengan proyek, tidak mudah untuk melepas dan memanggil kembali untuk bekerja sesuai dengan fluktuasi pekerjaan yang tersedia. Sedangkan menahan mereka untuk stand-by akan menelan biaya yang dipandang tidak efisien. Menurut Soeharto (1997) dalam rini (2014), tenaga kerja konstruksi dapat digolongkan menjadi dua macam. Yaitu penelia atau pengawas dan pekerja (Craft labor). Tenaga kerja konstruksi dapat dibedakan menjadi:

1. Tenaga kerja langsung (direct hire), yaitu tenaga kerja yang direkrut dan terdapat ikatan kontrak dengan perusahaan kontraktor. Umumnya diikuti dengan latihan sampai dianggap cukup memiliki pengetahuan dan kecakapan dasar.

2. Tenaga kerja borongan, yaitu tenaga kerja yang bekerja berdasarkan ikatan kerja yang ada antara perusahaan penyedia tenaga kerja dengan kontraktor untuk jangka waktu tertentu.

Tenaga kerja merupakan salah satu hal penting dalam pelaksanaan suatu proyek karena pengaruhnya cukup besar terhadap pembiayaan dan waktu penyelesaian suatu proyek konstruksi. Namun manusia itu merupakan sumber daya yang sulit diprediksi sehingga diperlukan usaha dan perencanaan dalam pengelolaan tenaga kerja. Dalam hal ini tenaga kerja konstruksi mencakup:

1. Pekerja yang mencakup pekerja tidak terampil, semi terampil dan pekerja terampil.

2. Teknisi terampil yang mencakup teknisi terampil administrasi dan teknisi terampil teknis.

3. Teknisi ahli dan teknisi profesional.

4. Tenaga manajemen yang dapat dikelompokkan menjadi manajemen terampil dan tenaga manajemen ahli.

Dalam pasal 1 angka 3 Kepmenaker No. KEP-150/MEN/1999 tahun 1999 tentang penyelenggaraan Program Jaminan Sosial Tenaga Kerja Bagi Tenaga Kerja Harian Lepas, Borongan dan Perjanjian Kerja Waktu tertentu yaitu bahwa tenaga kerja borongan adalah tenaga kerja yang bekerja pada pengusaha untuk melakukan pekerjaan tertentu dengan menerima upah didasarkan atas volume pekerjaan atau satuan hasil karya.

Menurut Undang-Undang Nomor 13 Tahun 2003 pasal 64 mengenai perjanjian pemborongan pekerjaan dan pada pasal 65 dijelaskan beberapa point penting mengenai pemborongan pekerjaan diantaranya yaitu:

1. Penyerahan sebagian pelaksanaan pekerjaan kepada perusahaan lain dilaksanakan melalui perjanjian pemborongan pekerjaan yang dibuat secara tertulis.

2. Pekerjaan yang dapat diserahkan kepada perusahaan lain sebagaimana maksud dalam ayat (1) harus memenuhi syarat sebagai berikut:

- Dilakukan secara terpisah dari kegiatan utama

- Dilakukan dengan perintah langsung atau tidak langsung dari pemberi pekerjaan.

3. Perusahaan lain sebagaimana dimaksud dalam ayat (1) harus berbentuk badan hukum.

4. Perlindungan kerja dan syarat-syarat kerja bagi pekerja/buruh pada perusahaan lain sebagaimana dimaksud dalam ayat (2) sekurang-kurangnya sama dengan perlindungan kerja dan syarat-syarat kerja pada perusahaan pemberi pekerjaan atau sesuai dengan peraturan perundang-undangan yang berlaku.

5. Perubahan dan/atau penambahan syarat-syarat sebagaimana dimaksud dalam ayat (2) diatur lebih lanjut dengan Keputusan Menteri.

Menurut ASCE, seseorang dapat dikatakan Professional Engineer apabila memiliki pengalaman diatas 4 tahun dan dapat dikatakan Engineer apabila memiliki pengalaman dibawah 4 tahun. Dalam penelitian ini akan dianalisis pendapat dari Professional Engineer dan para Engineer. 


\section{Produktivitas}

Menurut kamus Besar Bahasa Indonesia (1995), produktivitas berarti kemampuan untuk menghasilkan sesuatu daya untuk berproduksi. Menurut para ekonom, produktivitas pekerja didefinisikan sebagai rasio dari total produk output terhadap total produk input (Hanna et al.2005) dalam jurnal P.Kisi et al(2016) atau lebih simpel nya yaitu rasio output terhadap input (Rojas and Aramvareekul 2003a).

Menurut The U.S. Bureau Of Labor Statistics (2016), produktivitas didefinisikan sebagai output per jam kerja. Secara garis besar, produktivitas didefinisikan sebagai rasio input terhadap output dimana input dirujuk terhadap sumber daya manusia ( dalam hal ini manusia-hari atau manusia-jam) dan output merujuk pada sesuatu yang bernilai ekonomis.

\section{Faktor yang mempengaruhi produktivitas}

Produktivitas tenaga kerja dipengaruhi oleh beberapa faktor. Menurut Maloney (2016), terdapat 4 faktor besar yang mempengaruhi produktivitas tenaga kerja, yaitu Desain, pihak manajemen, karakteristik pekerja, dan peraturan pemerintah. Maloney juga mengatakan bahwa manajemen merupakan faktor yang paling mempengaruhi produktivitas pekerja.

Menurut Kisi.et al (2013) faktor faktor tersebut antara lain ialah faktor manajemen, karakteristik pekerja, kondisi lapangan, dan kondisi cuaca. Penjabaran dari grup faktor diatas adalah sebagai berikut :

- Faktor Teknikal seperti kelengkapan gambar serta koordinasi gambar, kompleks atau tidak nya suatu desain.

- Faktor Manajemen seperti kurangnya pengawasan, supervisor yang kurang kompeten, dan cara manajemennya (metode).

- Kondisi lingkungan seperti cuaca dingin atau panas. Lembab atau tidaknya lingkungan serta badai salju.

- Permasalahan scheduling seperti percepatan kegiatan, shift kerja, penempatan pekerja yang terlalu over pada suatu kegiatan dan atau lingkungan proyek yang terlalu padat.

- Permasalahan koordinasi seperti koordinasi yang tidak baik serta komunikasi yang kurang terkoordinasi.

- Perubahan dan Komisi seperti Change order dan Rework

- Karakteristik dari proyek seperti tipe kepemilikan proyek, keberhasilan proyek dan jenis pekerjaan.

- Karakteristik pekerja seperti jumlah dan kualitas pekerja. Faktor kesehatan serta kejenuhan dalam bekerja.

- Kondisi luar seperti lokasi proyek, regulasi pemerintah, tersedia atau tidaknya pekerja yang handal dan ketersediaan lapangan pekerjaan.

- Kegiatan yang tidak produktif seperti berdiam-diam, bekerja secara lambat, mengerjakan sesuatu yang tidak menguntungkan, kebanyakan istirahat serta keterlambatan.

- Faktor material seperti kekurangan material, pendataan material yang tidak teratur, serta kualitas material yang buruk.

- Faktor keamanan seperti kurangnya keamanan pada suatu proyek serta banyak atau tidaknya kecelakaan kerja.

Menurut Hafez et al (2014) Faktor faktor yang mempengaruhi produktivitas tenaga kerja ialah :

1. Faktor Manajemen

- Pembayaran yang terlambat

- Kurangnya supervisi

- Bekerja lembur

- Minimnya kepemimpinan dari konstruksi manajer

- Proporsi Kerja

- Metode Konstruksi

- Ukuran dari kelompok pekerja

- Lokasi Material yang tidak cocok

- Kekurangan material

- Adanya kecelakaan akibat kurangnya induksi safety

2. Faktor Teknikal

- Penjadwalan yang tidak realistik

- Kejelasan dari spesifikasi teknis

- Keterlambatan inspeksi

- Pengerjaan ulang

- Koordinasi antar divisi

- Tingkat kompleks suatu desain

- Sering terjadinya Change order pada saat pelaksanaan

- Kondisi lapangan/Site layout 
3. Faktor Manusia

- Larangan akses menuju lapangan

- Keterampilan dari tenaga kerja

- Tenaga kerja yang memiliki sedikit pengalaman

- Motivasi tenaga kerja

4. Faktor Eksternal

- Kelelahan Fisik

- Kelembaban yang tinggi

- Tinggi atau rendahnya suhu lingkungan

- Angin kencang

- Hujan

\section{METODE PENELITIAN}

Metode penelitian yang digunakan dalam penelitian ini adalah metode survei untuk mengetahui faktor yang mempengaruhi produktivitas pekerja pada bangunan high rise building. High rise building yang diteliti oleh peneliti berada di beberapa kota besar di Indonesia seperti Jakarta, Tangerang, Makassar, dan Batam. Penelitian ini dimulai dari studi literatur dilakukan untuk mengidentifikasi faktor-faktor apa saja yang mempengaruhi produktivitas tenaga kerja. Dari faktor-faktor tersebut, dilakukan pembuatan kuesioner dan disebarkan ke staff yang pernah bekerja pada bangunan bertingkat tinggi di Indonesia. Setelah data survey didapat, dilakukan uji validiitas dan uji reliabilitas untuk melihat faktor-faktor mana saya yang valid dan reliabel. Apabila faktor tidak valid atau reliabel, maka faktor tersebut dieliminasi dan dilakukan pengujian ulang. Setelah itu, dilakukan pemberian peringkat pada masing-masing faktor. Grup faktor serta sub faktor yang digunakan dalam penelitian ini dapat dilihat pada tabel 1, tabel 2 , tabel 3 dan tabel 4 di bawah.

Tabel 1. Variabel grup faktor manajemen

\begin{tabular}{cc}
\hline No & Faktor Manajemen \\
\hline FM1 & Keterlambatan pembayaran tenaga kerja \\
FM2 & Kurangnya pengawasan/supervisi tenaga kerja \\
FM3 & Jam kerja pekerja \\
FM4 & Penempatan serta akses material yang sulit \\
FM5 & Ketersediaan bahan material \\
FM6 & Kurangnya ketersediaan alat untuk menunjang kegiatan \\
FM7 & Kurangnya instruksi yang diberikan ke tenaga kerja \\
FM8 & Kurangnya disiplin koordinasi antar divisi (Struktur \\
FM9 & Kungan arsitek atau MEP) \\
FM10 & Cara berkomunikasi dalam mengatur tenaga kerja \\
FM11 & Pengawasan dan perhatian terhadap faktor keamanan \\
& kerja/safety
\end{tabular}

Tabel 2. Variabel grup faktor teknis

\begin{tabular}{cc}
\hline No & Faktor Teknis \\
\hline FT1 & Gambar yang sulit dimengerti atau belum lengkap \\
FT2 & spesifikasi teknis yang tidak jelas \\
FT3 & Pengerjaan ulang/Rework \\
FT4 & Desain yang sulit/ukuran elemen yang tidak seragam \\
FT5 & $\begin{array}{c}\text { Perubahan desain ketika pekerjaan sedang berjalan (Change Order) } \\
\text { FT6 }\end{array}$ \\
\cline { 2 - 2 } & Penggunaan Pre fabricated ( Beton pracetak, Formwork Self \\
\end{tabular}


Tabel 3. Variabel grup faktor tenaga kerja

\begin{tabular}{cc}
\hline No & Faktor Tenaga Kerja \\
\hline FTK1 & Kemampuan/Skill Pekerja \\
FTK2 & Pengalaman dari tenaga kerja \\
FTK3 & Motivasi para tenaga kerja \\
FTK4 & Kelelahan/Kejenuhan dari tenaga kerja \\
FTK5 & Kesalahpahaman antar tenaga kerja \\
\hline
\end{tabular}

Tabel 4. Variabel grup faktor eksternal

\begin{tabular}{cc}
\hline No & Faktor Eksternal \\
\hline FE1 & Suhu tinggi \\
FE2 & Hujan \\
FE3 & Bekerja diketinggian \\
FE4 & Kejadian Khusus (Wabah atau bencana alam) \\
\hline
\end{tabular}

Untuk pengukuran nilai kuesioner digunakan teknik pengukuran likert. Keterangan untuk skala pengukuran faktor yang mempengaruhi produktivitas pada proyek konstruksi:

1. Sangat tidak berpengaruh

2. Tidak terlalu berpengaruh

3. Cukup Berpengaruh

4. Berpengaruh

5. Sangat berpengaruh

Teknik pengolahan data yang digunakan untuk mengolah data hasil pengumpulan data yaitu:

1. Uji validitas

Pengukuran validitas dengan membandingkan nilai $\mathrm{r}$ perhitungan (Product Moment) dengan nilai $\mathrm{r}$ pada tabel. Jika nilai $\mathrm{r}$ hitung $\geq \mathrm{r}$ tabel, maka data tersebut sudah valid. Rumus dari $\mathrm{r}$ hitung adalah sebagai berikut:

$$
r_{x y}=\frac{n \sum x y-\left(\sum x\right)\left(\sum y\right)}{\sqrt{\left(n \sum x^{2}-\left(\sum x\right)^{2}\right)\left(n \sum y^{2}-\left(\sum y\right)^{2}\right)}}
$$

Keterangan :

$$
\begin{array}{ll}
\mathrm{x} & \text { : skor yang diperoleh subjek dari seluruh item } \\
\mathrm{y} & : \text { skor total yang diperoleh dari seluruh item } \\
\Sigma \mathrm{x} & : \text { jumlah skor dalam distribusi } \mathrm{x} \\
\Sigma \mathrm{y} & : \text { jumlah skor dalam distribusi } \mathrm{y} \\
\Sigma \mathrm{x}^{2} & : \text { jumlah kuadrat dalam skor distribusi } \mathrm{x} \\
\Sigma \mathrm{y}^{2} & : \text { jumlah kuadrat dalam skor distribusi } \mathrm{y}
\end{array}
$$

2. Uji Reliabilitas

Pengujian reliabilitas instrumen dengan menggunakan rumus Alpha Cronbach karena instrumen penelitian ini berbentuk angket dan skala bertingkat. Rumus untuk mencari nilai Cronbach's Alpha sebagai berikut::

Keterangan:

$$
r_{11}=\frac{\left({ }^{n}\right)}{n-1}\left(1-\frac{\sum \sigma_{t}^{2}}{\sigma_{t}{ }^{2}}\right)
$$

$$
\begin{array}{ll}
r_{11} & : \text { koefisien reliabilitas (nilai Cronbach's Alpha) } \\
\mathrm{n} & : \text { banyak butiran pernyataan } \\
\Sigma \sigma_{i}^{2} & : \text { jumlah varians skor soal ke-i } \\
\sigma_{t}{ }^{2} & : \text { jumlah varians skor total }
\end{array}
$$

3. Relative Importance Index

Setelah beberapa variabel/faktor dieliminasi dengan uji validitas dan reliabilitas, langkah selanjutnya dilakukan Relative Importance Index untuk mengetahui peringkat faktor yang mempengaruhi produktivitas tenaga kerja. 


$$
R I I(\%)=\frac{5 n 5+4 n 4+3 n 3+2 n 2+1 n 1}{W *(n 5+n 4+n 3+n 2+n 1)} \times 100 \%
$$

Keterangan:

$\begin{array}{ll}\text { n5 } & \text { : Jumlah responden yang memilih skala } 5 \\ \text { n4 } & \text { : Jumlah responden yang memilih skala } 4 \\ \text { n3 } & \text { : Jumlah responden yang memilih skala } 3 \\ \text { n2 } & \text { : Jumlah responden yang memilih skala } 2 \\ \text { n1 } & \text { : Jumlah responden yang memilih skala } 1 \\ \text { W } & \text { : Skala terbesar dalam skala likert }\end{array}$

\section{HASIL DAN PEMBAHASAN}

\section{Uji validitas}

Uji validitas merupakan uji untuk mengukur valid atau tidaknya suatu kuesioner. Uji validitas ini akan dilakukan dengan menggunakan program bantu dimana dengan metode analisis bivariate. Dimana inti dari analisis ini ialah untuk mengeluarkan nilai product moment ( $r$ hitung). Nilai $r$ hitung ini nantinya akan dibandingkan dengan nilai $r$ tabel dengan tingkat signifikansi 5\% dimana nilai $r$ tabel untuk responden sebanyak 30 orang yaitu 0,361 . Apabila nilai $r$ hitung lebih besar dari nilai $r$ tabel, maka variabel penelitian tersebut valid. Dikarenakan adanya keterbatasan format, maka hasil yang akan ditampilkan pada tabel 5 dibawah merupakan nilai $\mathrm{r}$ hitung.

Tabel 5. Nilai perhitungan product moment

\begin{tabular}{|c|c|c|c|}
\hline No & Nilai $r$ hitung & Nilai $r$ tabel & Keterangan \\
\hline FM1 & 0,380 & 0,361 & Valid \\
\hline FM2 & 0,668 & 0,361 & Valid \\
\hline FM3 & 0,598 & 0,361 & Valid \\
\hline FM4 & 0,665 & 0,361 & Valid \\
\hline FM5 & 0,378 & 0,361 & Valid \\
\hline FM6 & 0,351 & 0,361 & Tidak Valid \\
\hline FM7 & 0,661 & 0,361 & Valid \\
\hline FM8 & 0,401 & 0,361 & Valid \\
\hline FM9 & 0,616 & 0,361 & Valid \\
\hline FM10 & 0,556 & 0,361 & Valid \\
\hline FM11 & 0,652 & 0,361 & Valid \\
\hline FT1 & 0,546 & 0,361 & Valid \\
\hline FT2 & 0,789 & 0,361 & Valid \\
\hline FT3 & 0,621 & 0,361 & Valid \\
\hline FT4 & 0,760 & 0,361 & Valid \\
\hline FT5 & 0,515 & 0,361 & Valid \\
\hline FT6 & 0,793 & 0,361 & Valid \\
\hline FTK1 & 0,662 & 0,361 & Valid \\
\hline FTK2 & 0,137 & 0,361 & Tidak Valid \\
\hline FTK3 & 0,576 & 0,361 & Valid \\
\hline FTK4 & 0,797 & 0,361 & Valid \\
\hline FTK5 & 0,756 & 0,361 & Valid \\
\hline FE1 & 0,631 & 0,361 & Valid \\
\hline
\end{tabular}


Tabel 5. Nilai perhitungan product moment (Lanjutan)

\begin{tabular}{cccc}
\hline No & Nilai r hitung & Nilai r tabel & Keterangan \\
\hline FE2 & 0,526 & 0,361 & Valid \\
\hline FE3 & 0,640 & 0,361 & Valid \\
\hline FE4 & 0,591 & 0,361 & Valid
\end{tabular}

Pada uji validitas pertama, dapat dilihat bahwa variabel FM6 dan FTK2 tidak valid. Maka dari itu, akan dilakukan uji validitas untuk yang kedua kali nya tanpa variabel FM6 dan FTK2. Hasil uji validitas kedua dapat dilihat pada tabel 6 .

Tabel 6. Nilai perhitungan product moment

\begin{tabular}{|c|c|c|c|}
\hline No & Nilai $r$ hitung & Nilai $r$ tabel & Keterangan \\
\hline FM1 & 0,378 & 0,361 & Valid \\
\hline FM2 & 0,665 & 0,361 & Valid \\
\hline FM3 & 0,603 & 0,361 & Valid \\
\hline FM4 & 0,677 & 0,361 & Valid \\
\hline FM5 & 0,374 & 0,361 & Valid \\
\hline FM7 & 0,653 & 0,361 & Valid \\
\hline FM8 & 0,401 & 0,361 & Valid \\
\hline FM9 & 0,627 & 0,361 & Valid \\
\hline FM10 & 0,556 & 0,361 & Valid \\
\hline FM11 & 0,667 & 0,361 & Valid \\
\hline FT1 & 0,540 & 0,361 & Valid \\
\hline FT2 & 0,795 & 0,361 & Valid \\
\hline FT3 & 0,622 & 0,361 & Valid \\
\hline FT4 & 0,769 & 0,361 & Valid \\
\hline FT5 & 0,510 & 0,361 & Valid \\
\hline FT6 & 0,782 & 0,361 & Valid \\
\hline FTK1 & 0,660 & 0,361 & Valid \\
\hline FTK3 & 0,562 & 0,361 & Valid \\
\hline FTK4 & 0,799 & 0,361 & Valid \\
\hline FTK5 & 0,765 & 0,361 & Valid \\
\hline FE1 & 0,619 & 0,361 & Valid \\
\hline FE2 & 0,533 & 0,361 & Valid \\
\hline FE3 & 0,647 & 0,361 & Valid \\
\hline FE4 & 0,604 & 0,361 & Valid \\
\hline
\end{tabular}

\section{Uji reliabilitas}

Uji ini digunakan untuk mengetahui apakah alat ukur pada kuesioner ini konsistensi atau tidak. Uji ini menggunakan metode Alpha Conbrach's. Apa bila nilai Alpha Conbrach's kurang dari 0,6 maka alat ukur dikatakan tidak reliabel. Sedangkan dapat dikatakan sangat bagus apabila nilai tersebut lebih besar dari 0,9. Hasil perhitungan nilai Alpha Conbrach's dari beberapa grup faktor dapat dilihat pada tabel 7, tabel 8, tabel 9, dan tabel 10 . 
Tabel 7. Nilai output Cronbach's Alpha variabel manajemen

Reliability Statistics

\begin{tabular}{r|r}
$\begin{array}{c}\text { Cronbach's } \\
\text { Alpha }\end{array}$ & Nof Items \\
\hline 0,826 & 10 \\
\hline
\end{tabular}

Tabel 8. Nilai output Cronbach's Alpha variabel teknis

\section{Reliability Statistics}

\begin{tabular}{r|r}
$\begin{array}{l}\text { Cronbach's } \\
\text { Alpha }\end{array}$ & Nof Items \\
\hline 0,814 & 6 \\
\hline
\end{tabular}

Tabel 9. Nilai output Cronbach's Alpha variabel tenaga kerja

\section{Reliability Statistics}

\begin{tabular}{r|r}
\multicolumn{1}{c}{$\begin{array}{c}\text { Cronbach's } \\
\text { Alpha }\end{array}$} & Nof Items \\
\hline 0,793 & 4 \\
\hline
\end{tabular}

Tabel 10. Nilai output Cronbach's Alpha variabel eksternal

\section{Reliability Statistics}

\begin{tabular}{r|r}
$\begin{array}{l}\text { Cronbach's } \\
\text { Alpha }\end{array}$ & Nof Items \\
\hline 0,784 & 4
\end{tabular}

Berdasarkan uji reliabilitas di atas, dapat dilihat bahwa variabel pada penelitian ini sudah reliabel dimana nilai Cronbach's Alpha di atas 0,6.

\section{Relative Importance Index (RII)}

Untuk peringkat faktor, dilakukan peringkat secara umum serta peringkat menurut Professional Engineer dan Engineer. Seperti yang telah dijelaskan di bab sebelumnya, berdasarkan ASCE, Professional Engineer merupakan seseorang yang memiliki pengalaman di atas 4 tahun dan dapat dikatakan Engineer apa bila pengalamannya dibawah 4 tahun. Hasil perhitungan nilai RII untuk tiap variabel dapat dilihat pada tabel 11.

Tabel 11. Nilai perhitungan RII secara umum untuk setiap faktor

Faktor yang mempengaruhi produktivitas tenaga kerja RII

\section{Grup Faktor Manajemen}

\begin{tabular}{lc}
\hline Keterlambatan pembayaran tenaga kerja & 0,893333 \\
\hline Kurangnya pengawasan/supervisi terhadap tenaga kerja & 0,933333 \\
\hline Jam Kerja Pekerja & 0,813333 \\
\hline Penempatan serta akses material yang sulit & 0,84 \\
\hline
\end{tabular}


Tabel 11. Nilai perhitungan RII secara umum untuk setiap faktor (Lanjutan)

\begin{tabular}{ll}
\hline Faktor yang mempengaruhi produktivitas tenaga kerja & RII \\
\hline Ketersediaan bahan/material & 0,873333 \\
\hline Kurangnya instruksi yang diberikan ke tenaga kerja & 0,862069 \\
\hline Kurangnya disiplin koordinasi antar divisi (Struktur dengan arsitek & 0,88 \\
atau MEP) & 0,82 \\
\hline Kurangnya informasi mengenai penjadwalan proyek & 0,853333 \\
\hline Cara berkomunikasi dalam mengatur tenaga kerja & 0,8 \\
\hline Pengawasan dan perhatian terhadap faktor keamanan kerja/safety & 0,846667 \\
\hline Grup Faktor Teknis & 0,806667 \\
\hline Gambar yang sulit dimengerti atau belum lengkap & 0,893333 \\
\hline spesifikasi teknis yang tidak jelas & 0,76 \\
\hline Pengerjaan ulang/Rework & 0,886667 \\
\hline Desain yang sulit/ukuran elemen yang tidak seragam & 0,68 \\
\hline Perubahan desain ketika pekerjaan sedang berjalan & \\
\hline Penggunaan Pre fabricated (Beton pracetak, Formwork Self & \\
\hline
\end{tabular}

\section{Grup Faktor Tenaga Kerja}

\begin{tabular}{lc}
\hline Motivasi para tenaga kerja & 0,806667 \\
\hline Kelelahan/Kejenuhan dari tenaga kerja & 0,746667
\end{tabular}

Kesalahpahaman antar tenaga kerja $\quad 0,706667$

\begin{tabular}{lc}
\hline Grup Faktor Eksternal & \\
\hline Suhu tinggi & 0,62 \\
\hline Hujan & 0,78 \\
\hline Bekerja diketinggian & 0,666667 \\
\hline Kejadian khusus (Wabah penyakit atau bencana alam) & 0,86
\end{tabular}

Setelah dilakukan perhitungan RII untuk tiap variabel, selanjutnya dilakukan perhitungan RII untuk tiap grup faktor variabel guna menentukan grup faktor mana yang paling mempengaruhi produktivitas tenaga kerja. Hasil perhitungan untuk grup faktor variabel dapat dilihat pada tabel 12. 
Tabel 12. Nilai perhitungan RII rerata untuk grup faktor

\begin{tabular}{cc}
\hline $\begin{array}{c}\text { Grup faktor yang mempengaruhi } \\
\text { produktivitas tenaga kerja }\end{array}$ & Nilai rata-rata RII \\
\hline Grup Faktor Manajemen & 0,856874 \\
\hline Grup Faktor Teknis & 0,812222 \\
\hline Grup Faktor Tenaga Kerja & 0,77 \\
\hline Grup Faktor Eksternal & 0,731667 \\
\hline
\end{tabular}

Menurut ASCE, salah satu kriteria seseorang dapat dikatakan professional engineer adalah yang mempunyai pengalaman diatas 4 tahun. Perhitungan hasil RII menurut professional engineer dan engineer dapat dilihat pada tabel 13

Tabel 13. Nilai Perhitungan RII

\begin{tabular}{|c|c|c|}
\hline Faktor yang mempengaruhi produktivitas tenaga kerja & & III \\
\hline Grup Faktor Manajemen & $\begin{array}{l}\text { Professional } \\
\text { Engineer }\end{array}$ & Engineer \\
\hline Keterlambatan pembayaran tenaga kerja & 0,939 & 0,859 \\
\hline Kurangnya pengawasan/supervisi terhadap tenaga kerja & 0,939 & 0,93 \\
\hline Jam Kerja Pekerja & 0,862 & 0,859 \\
\hline Penempatan serta akses material yang sulit & 0,877 & 0,812 \\
\hline Ketersediaan bahan/material & 0,939 & 0,824 \\
\hline Kurangnya instruksi yang diberikan ke tenaga kerja & 0,862 & 0,863 \\
\hline $\begin{array}{l}\text { Kurangnya disiplin koordinasi antar divisi (Struktur dengan } \\
\text { arsitek atau MEP) }\end{array}$ & 0,893 & 0,871 \\
\hline Kurangnya informasi mengenai penjadwalan proyek & 0,847 & 0,8 \\
\hline Cara berkomunikasi dalam mengatur tenaga kerja & 0,831 & 0,871 \\
\hline $\begin{array}{l}\text { Pengawasan dan perhatian terhadap faktor keamanan } \\
\text { kerja/safety }\end{array}$ & 0,831 & 0,777 \\
\hline Grup Faktor Teknis & 0,831 & 0,706 \\
\hline Gambar yang sulit dimengerti atau belum lengkap & 0,862 & 0,838 \\
\hline spesifikasi teknis yang tidak jelas & 0,831 & 0,789 \\
\hline Pengerjaan ulang/Rework & 0,924 & 0,871 \\
\hline Desain yang sulit/ukuran elemen yang tidak seragam & 0,706 & \\
\hline Perubahan desain ketika pekerjaan sedang berjalan & 0,877 & 0,895 \\
\hline $\begin{array}{l}\text { Penggunaan Pre fabricated ( Beton pracetak, Formwork Self } \\
\text { Climbing)material }\end{array}$ & 0,662 & 0,695 \\
\hline
\end{tabular}


Tabel 13. Nilai perhitungan RII (Lanjutan)

\begin{tabular}{lcc}
\hline Grup Faktor Tenaga Kerja & & \\
\hline Motivasi para tenaga kerja & 0,8 & 0,812 \\
\hline Kelelahan/Kejenuhan dari tenaga kerja & 0,739 & 0,753 \\
\hline Grup Faktor Eksternal & 0,739 & 0,683 \\
\hline Kesalahpahaman antar tenaga kerja & 0,6 & 0,636 \\
\hline Suhu tinggi & 0,77 & 0,789 \\
\hline Hujan & 0,677 & 0,659 \\
\hline Bekerja diketinggian & 0,847 & 0,871 \\
\hline Kejadian khusus (wabah penyakit atau bencana alam) & & \\
\hline
\end{tabular}

\section{KESIMPULAN DAN SARAN}

\section{Kesimpulan}

Setelah dilakukan pengolahan data hasil penelitian, dapat ditarik kesimpulan beberapa hal yaitu:

1. Terdapat 4 Grup Faktor yang mempengaruhi produktivitas tenaga kerja yaitu grup faktor manajemen (RII : 0,856 ), grup faktor teknis ( RII : 0,8122), grup faktor tenaga kerja (RII : 0,77), dan grup faktor eksternal (RII : 0,7316)

2. Dari masing-masing grup faktor, sub faktor yang paling mempengaruhi adalah sebagai berikut:

1. Kurangnya pengawasan/supervisi terhadap tenaga kerja (Manajemen)

2. Pengerjaan ulang/Rework (Teknis)

3. Motivasi tenaga kerja (Tenaga kerja)

4. Kejadian khusus (Wabah penyakit atau bencana alam) (Faktor eksternal)

3. Terdapat 23 Faktor yang mempengaruhi produktivitas tenaga kerja pada bangunan bertingkat, dimana 10 faktor teratas yaitu sebagai berikut:

1 .Kurangnya pengawasan/supervisi terhadap tenaga kerja ( RII : 0,933 )

2. Pengerjaan ulang/Rework (RII : 0,8933)

2 .Keterlambatan pembayaran tenaga kerja (RII : 0,8933 )

3. Perubahan Desain ketika pekerjaan sedang berjalan ( RII : 0,886)

4. Kurangnya disiplin koordinasi antar divisi(Struktur dengan arsitek atau MEP) (RII : 0,88)

5. Ketersediaan bahan/material ( RII : 0,8733)

6. Kurangnya instruksi yang diberikan ke tenaga kerja (RII : 0,8621)

7. Kejadian khusus (Wabah penyakit atau bencana alam) (RII : 0,86 )

8. Cara berkomunikasi dalam mengatur tenaga kerja (RII : 0,8533 )

9. Gambar yang sulit dimengerti atau belum lengkap (RII : 0,84667)

10. Penempatan serta akses material yang sulit (RII : 0,84$)$

4. Terdapat 5 faktor dengan nilai RII tertinggi menurut Engineer (Pengalaman dibawah 4 tahun) adalah sebagai berikut:

-Kurangnya pengawasan/supervisi terhadap tenaga kerja (RII : 0,93)

-Kurangnya disiplin koordinasi antar divisi (Struktur dengan arsitek atau MEP) (RII : 0,895)

-Perubahan desain ketika pekerjaan sedang berjalan ( RII : 0,871)

-Cara berkomunikasi dalam mengatur tenaga kerja (RII : 0,87) 
-Kejadian khusus (Wabah penyakit atau bencana alam) (RII : 0,87)

5. Menurut ASCE, Professional Engineer adalah seorang Engineer dengan pengalaman kerja lebih dari 4 tahun dimana 5 faktor dengan nilai RII tertinggi menurut Professional Engineer dalam penelitian ini adalah sebagai berikut:

- Kurangnya pengawasan/supervisi terhadap tenaga kerja (RII : 0,939)

- Keterlambatan pembayaran tenaga kerja (RII : 0,939)

- Ketersediaan bahan material (RII : 0,939)

- Pengerjaan Ulang/Rework (RII : 0,924)

- Perubahan desain ketika pekerjaan sedang berjalan (RII : 0,877)

\section{Saran}

Peneliti akan memberikan saran kebeberapa pihak dalam penelitian ini. saran ini ditujukan kepada peneliti selanjutnya serta ke pihak manajemen suatu proyek gedung bertingkat.

1. Untuk penelitian berikutnya, dapat ditambahkan dengan meneliti nilai manpower. Perhitungan manpower dilakukan serta mengidentifikasi faktor-faktor yang mempengaruhi angka manpower tersebut dalam satu lingkup proyek saja.

2. Untuk para pihak supervisor/pengawas untuk lebih memerhatikan kinerja para tenaga kerja yang bersangkutan, dikarenakan faktor ini merupakan faktor yang paling mempengaruhi dalam produktivitas tenaga kerja.

3. Diadakan program/protokol agar tenaga kerja dapat tetap produktif apabila terjadi kejadian khusus. Hal ini dikarenakan dari grup faktor eksternal yang paling mempengaruhi yaitu faktor "Kejadian khusus seperti wabah penyakit atau bencana alam”. Faktor ini peneliti gunakan dikarenakan disaat penelitian ini berlangsung, tengah terjadi wabah pandemi yang cukup meresahkan bagi masyarakat.

\section{DAFTAR PUSTAKA}

Ervianto, Wulfram I. Manajemen Proyek Konstruksi. Yogyakarta: Andi Ofset, 2005.

Hafez, Sherif M., et al. "Critical factors affecting construction labor productivity in Egypt." American Journal of Civil Engineering (2014): 35-40.

Kementrian Tenaga Kerja. "Keputusan Menteri Tenaga Kerja NO. KEP-150/MEN/1999 Penyelenggaraan Program Jaminan Sosial Tenaga Kerja." n.d.

Kisi, Krishna P, et al. "Optimal Productivity in Labor-Intensive Construction Operations: Pilot Study." (2016).

Rani, Hafnidar A. Manajemen Proyek Konstruksi. 2016.

Rivas, Rodrigo A., et al. "Analysis of Factors Influencing Productivity Using Craftsmen Questionnaires: Case Study in a Chilean Construction Company." (2015).

Soeharto, Iman. Manajemen Proyek. Jakarta: Erlangga, 1999.

"Undang-Undang Republik Indonesia Nomor 13 Tahun 2003 Tentang Ketenagakerjaan." n.d. 
